\title{
Espécies de Panurgillus Schlindwein \& Moure (Hymenoptera, Andrenidae) depositados no Naturkunde Museum, Berlin ${ }^{1}$
}

\author{
Clemens Schlindwein ${ }^{2}$ \\ Jesus Santiago Moure ${ }^{3}$
}

\begin{abstract}
Species of Panurgillus Schlindwein \& Moure (Hymenoptera, Andrenidae), deposited in the Naturkunde Museum, Berlin. The bees described as Panurginus Nylander, 1848, from southern South America and deposited in the Museum Humboldt, Berlin, were studied. Seven species were redescribed and transferred to the genus Panurgillus Schlindwein \& Moure, 1998: P. aeneiventris (Friese, 1908), P. brunneicornis (Strand, 1910), P. paraguayanus (Strand, 1910), P. pauloensis (Friese, 1916), P. saltensis (Friese, 1908), P. solani (Ducke, 1912) e P. steinbachi (Friese, 1916). A key for the identification of the 21 known species of the genus is included. Panurginus flaviceps Friese, 1916 and $P$. saltensis var. nigroclypeata Friese, 1908 described by Friese are synonyms of Anthrenoides meridionalis (Schrottky, 1906). Panurginus laticeps Friese, 1916 belongs to Cephalurgus Moure \& Oliveira, 1962 and P. nigriceps Friese is a species of Bicolletes Friese, 1908 (Colletidae, Paracolletini).

KEY WORDS. Hymenoptera, Apoidea, Andrenidae, Panurginae, Panurgillus, South America.
\end{abstract}

Recentemente foi descrito o gênero Panurgillus com 14 espécies do Sul do Brasil e da Argentina (SCHLINDwEIN \& Moure 1998). Na coleção do "Museum für Naturkunde, Humboldt Universität, Berlin" (MNHU), encontravam-se várias espécies, descritas como Panurginus Nylander, 1848 por FrIESE $(1908,1916)$, DUCKE $(1908,1912)$ e STRAND (1910) com procedência da América do Sul. Panurginus alismatis Ducke, 1908 e $P$. decoloratus Ducke, 1908 já tinham sido transferidos para o gênero Pasiphae Spinola, 1851 (=Bicolletes Friese, 1908, Colletidae, Paracolletini) anteriormente por DUCKE (1912) e mais recentemente por MiCHENER (1989), P. palpalis Ducke, 1908, para Protodiscelis Brèthes, 1909.

Com as espécies encontradas no Museum Humboldt, o gênero Panurgillus abrange 21 espécies e ocorre, na Argentina, do oeste da Província de Salta (Andes) e, ao sul até a Província de Buenos Aires, ao norte, chega até o estado do Rio de Janeiro no Brasil.

\section{MATERIAL E MÉTODOS}

As medidas foram feitas com ocular micrométrica em microscópio estereoscópico Wild M8. O comprimento dos pêlos é aproximado, medido com aumento

1) Contribuição número 1087 do Departamento de Zoologia, Universidade Federal do Paraná.

2) Departamento de Botânica, Universidade Federal de Pernambuco. Avenida Prof. Moraes Rêgo, 50670-901 Recife, Pernambuco, Brasil.

3) Departamento de Zoologia, Universidade Federal do Paraná. Caixa Postal 19020, 81531-990 Curitiba, Paraná, Brasil. 
de 50x. Os intervalos entre os pontos estão indicados pelo número de "diâmetros de ponto" que os separam, assim um intervalo de três diâmetros é indicado com $3 \mathrm{dp}$. Outras abreviaturas do texto são: $(\varnothing)$ diâmetro, (T) tergo, (E) esterno. As etiquetas do exemplar entre colchetes [].

\section{RESULTADOS E DISCUSSÃO}

\section{Panurgillus aeneiventris (Friese, 1908) comb.n.}

Panurginus aeneiventris Friese, 1908: 27.

Lectótipo, fêmea, e lectoalótipo macho no MNHU. Etiquetas na fềmea: [Argentina, Salta, 2500, 3.1905, Steinbach]; [Type] = vermelho; $[$ Panurginus aeneiventris Fr. 1907 Friese det.]; [Zool. Mus. Berlin]. No macho: [Argentina, Salta, 1200, 3.1905, Steinbach]. As outras etiquetas como na fêmea.

Diagnose. Clípeo fortemente reticulado; pontuação muito densa na metade superior da face; intervalos entre os pontos no mesoscuto liso-brilhantes; pernas inteiramente pretas; pronoto com pêlos plumosos; olhos subparalelos; sete hâmulos, metasoma com fraco brilho cúpreo; macho com o clípeo branco menos os cantos laterais, sem manchas escuras perto das fóveas tentoriais anteriores; com retículo muito forte na metade inferior da face; as pernas sem desenhos amarelos; com cerdas eretas escuras no T4, T5 e T6 numa faixa perto da depressão marginal.

Lectótipo, fêmea. Comprimento total aproximado 5,4 mm; asa anterior 3,9 $\mathrm{mm}$; largura da cabeça $1,78 \mathrm{~mm}$; comprimento da cabeça $1,46 \mathrm{~mm}$; largura do metasoma $1,74 \mathrm{~mm}$.

Tegumento preto, flagelo amarelo-pálido por baixo; tégula translúcida. Asas levemente fuscas, com veias e pterostigma castanho-claros, pernas inteiramente pretas. Depressões marginais dos tergos translúcidas.

Pilosidade esbranquiçada, esparsa; no vértice e face até $0,2 \mathrm{~mm}$, no escapo até $0,18 \mathrm{~mm}$. No pronoto, metanoto, mesepisternos e nos flancos do propódeo até $0,2 \mathrm{~mm}$; no mesoscuto muito curta (até $0,06 \mathrm{~mm}$ ), porém com alguns pêlos mais compridos intercalados anteriormente; lado ventral do mesepisterno sem pêlos em gancho; pêlos da escopa brancos com cerdas não plumosas, esparsas (cerca de 0,4 $\mathrm{mm})$. Área basal do propódeo com pêlos plumosos $(0,6 \mathrm{~mm})$; cerdas no T5 até 0,5 $\mathrm{mm}$ e com curta franja apical.

Pontuação muito densa na metade superior da face e no vértice $(\varnothing 0,03-0,04$ $\mathrm{mm},<1 / 2 \mathrm{dp}$ ), mais esparsa nas genas; na metade inferior abaixo dos alvéolos mais grossa e esparsa, especialmente no clípeo, os intervalos entre os pontos fortemente reticulados. No mesoscuto profunda e densa (cerca de $0,02 \mathrm{~mm}, \leq 1 \mathrm{dp}$ ), os intervalos lisos e brilhantes; no escutelo um pouco mais grossa; no metanoto muito densa, com retículo; os mesepisternos fortemente reticulados. Propódeo com retículo muito forte e também próximo à área basal, por isso a pontuação pouco evidente; nos tergos fina (intervalos 1-2dp), ficando mais esparsa próximo às depressões marginais, os intervalos reticulados e com fraco brilho cúpreo; no $\mathrm{T} 5 \mathrm{com}$ pontos mais grossos e mais esparsos; as depressões marginais dos tergos micropontuadas.

Comprimento do olho $1 \mathrm{~mm}$, largura $0,6 \mathrm{~mm}$; distâncias interorbitais superior $1,12 \mathrm{~mm}$, média $1,1 \mathrm{~mm}$ e inferior $1,04 \mathrm{~mm}$; distância interalveolar $0,26 \mathrm{~mm}$; alveolorbital $0,3 \mathrm{~mm}$; alveolocelar $0,54 \mathrm{~mm} ; \varnothing$ alvéolo $0,14 \mathrm{~mm}$; interocelar 0,2 
$\mathrm{mm}$; ocelorbital $0,38 \mathrm{~mm}$; $\varnothing$ ocelo médio $0,14 \mathrm{~mm}$; comprimento das suturas subantenais: externa $0,34 \mathrm{~mm}$, interna $0,2 \mathrm{~mm}$, largura da área subantenal $0,14 \mathrm{~mm}$; comprimento do clípeo $0,46 \mathrm{~mm}$, largura $1,1 \mathrm{~mm}$; clipeocelar $0,72 \mathrm{~mm}$; linha frontal pouco evidente; fóvea facial bem marcada, lisa, comprida e estreita, comprimento $0,3 \mathrm{~mm}$, largura $0,07 \mathrm{~mm}$; largura do labro $0,5 \mathrm{~mm}$, a placa labral lisa com os lados convergentes e 0 ápice quase em linha reta, com rúgulas longitudinais, comprimento $0,26 \mathrm{~mm}$, largura 0,32 mm; escapo 0,42: $0,14 \mathrm{~mm}$; flagelo ligeiramente clavado, os três primeiros flagelômeros $0,14: 0,1: 0,08 \mathrm{~mm}, \varnothing$ do terceiro $0,14 \mathrm{~mm}$, o maior $\varnothing$ $0,17 \mathrm{~mm}$; flagelo e pedicelo juntos cerca de $1,28 \mathrm{~mm}$. Sete hâmulos; fêmur médio com ângulo; basitarso médio duas vezes mais longo que largo, comprimento 0,46 $\mathrm{mm}$, largura $0,24 \mathrm{~mm}$. Área basal do propódeo semilunar, com muitas carenas curtas, subparalelas, interrompidas; T2 com as fóveas laterais pouco evidentes, comprimento $0,4 \mathrm{~mm}$, largura $0,14 \mathrm{~mm}$.

Lectoalótipo macho. Tamanho: comprimento total aproximado $4,9 \mathrm{~mm}$; asa anterior $3,8 \mathrm{~mm}$; largura da cabeça $1,66 \mathrm{~mm}$; comprimento da cabeça $1,34 \mathrm{~mm}$; largura do metasoma $1,42 \mathrm{~mm}$.

Tegumento preto; o clípeo branco menos os cantos laterais, sem manchas pretas perto das fóveas tentoriais anteriores; mandíbulas translúcidas, amarelo-claras; flagelo castanho embaixo. Tégulas pouco translúcidas; asas subhialinas com as veias e pterostigma castanhos; pernas inteiramente pretas. Depressões marginais dos tergos pouco transparentes; metasoma com fraco brilho cúpreo.

Pilosidade esbranquiçada, esparsa, rala; na cabeça cerca de $0,2 \mathrm{~mm}$, alguns pêlos mais compridos no clípeo, no escapo até $0,26 \mathrm{~mm}$. No mesoscuto curta e com alguns pêlos compridos intercalados, como na fêmea; no escutelo, no metanoto e nos mesepisternos como na cabeça. Curta e plumosa na área basal do propódeo; nos flancos como na cabeça; com cerdas eretas escuras em T4-6 numa faixa perto da depressão marginal, comprimento no T6 0,3 mm; E5 e E6 com pêlos amarelados nos lados, direcionados ao meio.

Pontuação muito densa na metade superior da face e no vértice (cerca de 0,03 $\mathrm{mm},<1 / 2 \mathrm{dp}$ ); clípeo e áreas paroculares inferiores com retículo muito forte e pontuação mais esparsa, especialmente no clípeo. No mesoscuto forte e densa $(<1 / 2 \mathrm{dp})$; no escutelo um pouco mais grossa e esparsa; no metanoto muito densa, os intervalos fortemente reticulados. Propódeo posteriormente com retículo muito forte até a área basal; pontos nos tergos finos, $\varnothing$ diminuindo de T1 para T5, os intervalos lisos até finamente reticulados (1-2dp); T6 com pontos grossos; depressões marginais micropontuadas, ficando mais fraca nos últimos tergos.

Comprimento do olho $0,96 \mathrm{~mm}$, largura $0,64 \mathrm{~mm}$; olhos fortemente convergentes para baixo, distâncias interorbitais: superior $1,04 \mathrm{~mm}$, média $0,9 \mathrm{~mm}$, inferior $0,7 \mathrm{~mm}$; distância interalveolar $0,2 \mathrm{~mm}$; alveolorbital $0,18 \mathrm{~mm}$; alveolocelar 0,52 $\mathrm{mm}$; $\varnothing$ alvéolo $0,12 \mathrm{~mm}$; interocelar $0,18 \mathrm{~mm}$; ocelorbital $0,34 \mathrm{~mm}$; $\varnothing$ ocelo médio $0,15 \mathrm{~mm}$; suturas subantenais pouco evidentes, externa $0,3 \mathrm{~mm}$, interna $0,22 \mathrm{~mm}$, largura da área subantenal $0,09 \mathrm{~mm}$; clípeo protuberante, comprimento $0,38 \mathrm{~mm}$, largura $0,9 \mathrm{~mm}$; clipeocelar $0,76 \mathrm{~mm}$; linha frontal pouco evidente; fóvea facial lisa, bem marcada, pequena, comprimento $0,14 \mathrm{~mm}$, largura $0,04 \mathrm{~mm}$; largura do labro $0,46 \mathrm{~mm}$; placa labral lisa, os lados convergentes, o ápice em linha reta, compri- 
mento $0,15 \mathrm{~mm}$, largura $0,28 \mathrm{~mm}$; comprimento e $\varnothing$ máximo do escapo $0,32: 0,15$ $\mathrm{mm}$; os três primeiros flagelômeros $0,16: 0,1: 0,11 \mathrm{~mm}, \varnothing$ do terceiro $0,14 \mathrm{~mm}$ e o maior $\varnothing 0,16 \mathrm{~mm}$; flagelo e pedicelo juntos $1,42 \mathrm{~mm}$. Seis hâmulos; basitarso médio cerca de quatro vezes mais longo que largo $(0,46: 0,12 \mathrm{~mm})$. Área basal do propódeo semilunar, com carenas curtas subparalelas; T2 com as fóveas laterais rasas $(0,09: 0,06 \mathrm{~mm})$.

Comentário. Semelhante a P. malvacearum Schlindwein \& Moure, 1998 e P. reticulatus Schlindwein \& Moure, 1998 pelo retículo forte no clípeo e pela ausência das manchas amarelas nas tíbias anteriores e médias. Difere pelos intervalos lisos no mesoscuto, pelo brilho cúpreo no metasoma e pelo número de hâmulos. $\mathrm{O}$ macho se distingue pelo clípeo branco sem manchas perto das fóveas tentoriais anteriores e pela presença de cerdas eretas em faixas em T4-T6.

Distribuição geográfica. ARGENTINA: Salta.

\section{Panurgillus brunneicornis (Strand, 1910) comb.n.}

Panurginus brunneicornis Strand, 1910: 497

Holótipo fêmea (único exemplar) no MNHU. Etiquetas: [Asunción, Paraguay, C.S. Miguel, 7.X.1905, J.D. Anisits]; [Type] (vermelho); [Panurginus brunneicornis $\mathrm{m}$. Strand det.]; [Zool. Mus. Berlin].

Diagnose: olhos fracamente convergentes para baixo; fóveas faciais longas e estreitas. Pontuação no mesoscuto fina e densa na frente, mais fina e esparsa (2dp) no disco, mais densa entre as parápsides e os lados e com alguns pontos maiores muito espalhados, com micro-reticulação muito delicada nos intervalos; no escutelo claramente mais grossa; pêlos no lado ventral do mesosoma em gancho; tíbias anteriores e médias com pequena mancha amarela na base; tarsos dos três pares de pernas ocres. 8-9 hâmulos. T1 quase sem pontos, em grande parte polido e brilhante: a pontuação moderadamente forte, separada por $1,5 \mathrm{dp}$ formando uma faixa transversal no terço médio, na depressão marginal mais fina, tesselada, em faixa estreitada para os lados; T2-4 pontuados. a pontuação mais fina e mais densa nos três quartos basais seguida no quarto distal por uma área mais delicadamente micro-pontilhado-reticulada, nas depressões marginais ainda mais fina e superficial.

Holótipo, fêmea. Comprimento total aproximado 5,4 mm; asa anterior 3,5 $\mathrm{mm}$; largura da cabeça $1,7 \mathrm{~mm}$; comprimento da cabeça $1,6 \mathrm{~mm}$; largura do metasoma $1,94 \mathrm{~mm}$.

Tegumento preto; com o flagelo um pouco brunescente por baixo; mandíbulas castanho-escuras. Tégulas amarelento-translúcidas; asas subhialinas, levemente irisadas, veias e pterostigma castanho-claros; tíbias anteriores e médias com uma pequena mancha amarela na base; tarsos de todos os pares liegeiramente mais claros que as tíbias, ocráceos. Depressões marginais dos tergos quase tão escuras como a parte discal.

Pilosidade esbranquiçada, curto-denso-plumosa, um pouco mais longa na face $(0,1 \mathrm{~mm})$ e nas genas; pêlos no escapo até $0,08 \mathrm{~mm}$. No pronoto e parte anterior do mesoscuto muito curta (até $0,05 \mathrm{~mm}$ ), densa; no escutelo mais longa $(0,2 \mathrm{~mm})$; lado ventral do mesosoma com pêlos finos em gancho; escopa branca com cerdas 
não plumosas, esparsas, um pouco curvas (até $0,4 \mathrm{~mm}$ ). Em T5 até $0,4 \mathrm{~mm}$, a franja com as pontas pretas.

Pontuação na fronte fina, um pouco alongada e os intervalos lisos até $2 \mathrm{dp}$, mais densa junto a linha frontal; na metade inferior da face mais grossa e mais esparsa, no clípeo até $0,05 \mathrm{~mm}$ e os intervalos até $2 \mathrm{dp}$; nas paroculares inferiores os intervalos muito lisos (até $3 \mathrm{dp}$ ) até as fóveas faciais; nas áreas ocelorbitais mais esparsa em direção aos ocelos; na supraclipeal um pouco mais fina que no clípeo; nas genas bastante mais fina e esparsa, os intervalos lisos; no vértice mais grossa e esparsa. No mesoscuto mais fina e mais densa que na fronte, um pouco mais densa na metade anterior $(0,01 \mathrm{~mm}, 1-2 \mathrm{dp})$, os intervalos delicadamente reticulados. No escutelo claramente mais grossa os intervalos $1,5-2 \mathrm{dp}$, com retículo pouco perceptível; no metanoto densa; nos mesepisternos quase como no escutelo, com o retículo bastante mais forte. No propódeo sem pontos junto a área basal, porém com retículo fraco, na face posterior os pontos mais evidentes (1-1,5dp), nos flancos fina e os intervalos reticulados; T1 quase sem pontos, liso e polido para a base, para o meio mais pontuado, a depressão margianl reticulada; T2 e seguintes com pontuação fina, adensada para a base, muito esparsa para a depressão marginal, os intervalos finamente reticulados até lisos posteriormente; as depressões marginais mais fortemente reticuladas; em T5 mais grossa com as cerdas plumosas.

Comprimento do olho $0,9 \mathrm{~mm}$, largura $0,48 \mathrm{~mm}$; olhos fracamente convergentes para baixo, com as distâncias interorbitais maiores que o comprimento do olho, a superior $1,26 \mathrm{~mm}$, a média $1,2 \mathrm{~mm}$ e a inferior $1,14 \mathrm{~mm}$; distância interalveolar $0,24 \mathrm{~mm}$; alveolorbital $0,36 \mathrm{~mm}$; alveolocelar $0,4 \mathrm{~mm}$; $\varnothing$ alvéolo 0,12 $\mathrm{mm}$; interocelar $0,24 \mathrm{~mm}$; ocelorbital $0,4 \mathrm{~mm}$; $\varnothing$ ocelo médio $0,12 \mathrm{~mm}$; suturas subantenais pouco visíveis, a externa $0,32 \mathrm{~mm}$, interna $0,3 \mathrm{~mm}$, largura da área subantenal $0,13 \mathrm{~mm}$; comprimento do clípeo $0,56 \mathrm{~mm}$, largura $1,0 \mathrm{~mm}$; clipeocelar $0,75 \mathrm{~mm}$; linha frontal sulciforme bem evidente no fundo da depressão antecedente ao ocelo médio; fóveas faciais fortes, estreitas e longas, lisas, comprimento 0,45 $\mathrm{mm}$, largura $0,04 \mathrm{~mm}$, alargadas para cima até $0,08 \mathrm{~mm}$; largura do labro $0,58 \mathrm{~mm}$, placa labral lisa, sem rúgulas, um pouco estreitada para o ápice, truncada de cantos arredondados, comprimento $0,24 \mathrm{~mm}$, largura $0,28 \mathrm{~mm}$; escapo $0,56: 0,15 \mathrm{~mm}$; flagelo fracamente clavado, os três primeiros flagelômeros $0,12: 0,08: 0,1 \mathrm{~mm}, \varnothing$ do terceiro $0,16 \mathrm{~mm}$; maior $\varnothing 0,2 \mathrm{~mm}$; flagelo e pedicelo juntos $1,5 \mathrm{~mm}$. Nove a dez hâmulos; fêmur médio por baixo em ângulo obtuso muito aberto com o vértice um pouco arredondado; basitarso médio $(0,56: 0,22 \mathrm{~mm})$, cerca de 2,5 mais longo que largo, o posterior um pouco projetado por trás do segundo tarsômero $(0,76: 0,2 \mathrm{~mm})$. Área basal do propódeo em arco um pouco acuminado no meio, a carena média e as laterais um pouco irregulares apicalmente, mais curtas que o comprimento da área basal; T2 com as fóveas laterais bastante fortes $(0,32: 0,16 \mathrm{~mm})$; placa pigidial rebordada em ogiva subtruncada apicalmente e elevada ao longo do meio.

Macho desconhecido.

Comentário. Pelo primeiro tergo bastante brilhante e polido, lembra $P$. politus Schlindwein \& Moure, 1998. Separa-se facilmente pela pontuação e pilosidade do mesoscuto, pontuação do escutelo e mesepisternos; hâmulos 9-10. Em $P$. politus o T1 ainda é muito mais liso que na espécie de Strand. Pela chave de 
Panurgillus (Schlindwein \& Moure, 1998) chega-se mal ao dilema 6, pois a pontuação geral do mesoscuto em geral esparsa, com os intervalos iguais ou maiores que $2 \mathrm{dp}$, bastante lisos, porém a pilosidade curta, menos da metado do $\varnothing$ escapo, as fóveas faciais um pouco alargadas para cima.

Comparando-se com as três espécies incluidas no dilema separa-se facilmente das mesmas: de P. flavitarsis Schlindwein \& Moure, 1998 pelo colorido dos tarsos castanho-claros, e pilosidade do tórax; de P. harterae Schlindwein \& Moure, 1998, pela pilosidade do tórax mais curta, formato das fóveas faciais e das fóveas laterais do T2, os pontos no mesoscuto mais grossos e os intervalos reticulados; de $P$. plumosulus Schlindwein \& Moure, 1998 pela pilosidade do tórax muito mais curta, os intervalos densa e fortemente reticulados. Entrando no dilema 9, difere de $P$. eustictus Schlindwein \& Moure, 1998 pela pontuação forte do mesoscuto e intervalos reticulados, T1 mate-reticulado e T2 com fóveas laterais fracas; de P. holostictus Schlindwein \& Moure, 1998 pela pontuação do tórax e do metasoma, pelas fóveas faciais e pelas fóveas laterais de $\mathrm{T} 2$.

Distribuição geográfica. Paraguai.

\section{Panurgillus paraguayanus (Strand, 1910) comb.n.}

Panurginus paraguayanus Strand, 1910: 496-497.

Lectótipo e dois paralectótipos, fêmeas, no MNHU. O Lectótipo com as etiquetas: [Paraguay, S. Amer., Villa Morra, 7.XII.04, J.D. Anisits]; [Type] (vermelha); [Panurginus paraguayanus m., Strand det.]; [Zool. Mus. Berlin].

Os parátipos com a mesma procedência e coletor, e a etiqueta Cotype (vermelho). Um exemplar coletado em 19.XII.04, o outro em 9.XI.05.

Diagnose: Fêmea com os lóbulos pronotais amarelos; tíbia das pernas anteriores e médias com uma mancha amarela na base; lado posterior do propódeo densamente pontuado até a área basal; T1-T4 densamente pontuados, as depressões marginais micropontuadas; olhos subparalelos; placa labral larga, subretangular; mesoscuto com pêlos curtos; lado ventral do mesepisterno com pêlos em gancho; fêmures médios com dente na face ventral.

Lectótipo, fêmea. Comprimento total aproximado $6 \mathrm{~mm}$; asa anterior 4,48 $\mathrm{mm}$; largura da cabeça $1,76 \mathrm{~mm}$; comprimento da cabeça $1,56 \mathrm{~mm}$; largura do metasoma $1,74 \mathrm{~mm}$.

Tegumento castanho-escuro até preto; as mandíbulas castanhas; o flagelo amarelo-ocre por baixo; lóbulos pronotais amarelos. Tégulas translúcidas; asas subhialinas, levemente esfumaçadas; veias e pterostigma castanhos; tíbias anteriores e médias com uma mancha amarela na base; pernas castanhas até ocres. Depressões marginais dos tergos fracamente translúcidas.

Pilosidade esbranquiçada, rala e curta; na face, no vértice e nas genas até $0,16 \mathrm{~mm}$; pêlos no escapo até $0,1 \mathrm{~mm}$. Curta no mesoscuto (cerca de $0,06 \mathrm{~mm}$ ), mais comprida e plumosa no metanoto e nos mesepisternos; lado ventral do mesepisterno com pêlos finos em gancho; escopa inteiramente branca com cerdas pouco plumosas, recurvadas, cerca de $0,38 \mathrm{~mm}$. Área basal do propódeo com pêlos plumosos (cerca de $0,1 \mathrm{~mm}$ ), densos; mais comprida e plumosa nos flancos do propódeo; no T5 $0,35 \mathrm{~mm}$ e com curta franja apical.

Revta bras. Zool. 16 (Supl. 1): 113 - 133, 1999 
Pontuação relativamente grossa na face com os intervalos lisos e alguns micropontos intercalados, na metade superior cerca de $0,03 \mathrm{~mm},<1 \mathrm{dp}$, na metade inferior um pouco mais grossa e um pouco mais esparsa; na área ocelorbital uma área lisa, sem pontos ao lado dos ocelos laterais; nas genas densa $(<1 \mathrm{dp})$. No mesoscuto fina $(0,02 \mathrm{~mm}, 1->2 \mathrm{dp})$, os intervalos com retículo muito fraco; no escutelo e metanoto cerca de $0,04 \mathrm{~mm}$, os intervalos lisos; no escutelo cerca de $1 \mathrm{dp}$; no metanoto mais densa; nos mesepisternos grossa e muito densa $(<1 / 2 \mathrm{dp})$. No face posterior do propódeo densa $(0,02 \mathrm{~mm},<1 \mathrm{dp})$ até a área basal; pontuação nos tergos fina e densa $(0,02 \mathrm{~mm}$, cerca de $1 \mathrm{dp})$, os intervalos com retículo muito fraco, brilhante, pontuação um pouco mais esparsa perto das depressões marginais, estas com pontuação muito densa e fina; no T5 mais grossa e esparsa.

Comprimento do olho $1,08 \mathrm{~mm}$, largura $0,58 \mathrm{~mm}$; olhos subparalelos, distâncias interorbitais: superior $1,12 \mathrm{~mm}$, média $1,08 \mathrm{~mm}$, inferior $1,04 \mathrm{~mm}$; distância interalveolar $0,3 \mathrm{~mm}$; alveolorbital $0,3 \mathrm{~mm}$; alveolocelar $0,48 \mathrm{~mm}$; $\varnothing$ alvéolo $0,14 \mathrm{~mm}$; interocelar $0,26 \mathrm{~mm}$; ocelorbital $0,36 \mathrm{~mm}$; $\varnothing$ ocelo médio 0,18 $\mathrm{mm}$; comprimento das suturas subantenais: externa $0,38 \mathrm{~mm}$, interna $0,32 \mathrm{~mm}$, largura da área subanteanal $0,12 \mathrm{~mm}$; comprimento do clípeo $0,48 \mathrm{~mm}$, largura 1,04 $\mathrm{mm}$; clipeocelar $0,74 \mathrm{~mm}$; linha frontal sulciforme na metade inferior, careniforme na metade superior até o ocelo médio; fóveas faciais estreitas, bem marcadas, lisas, comprimento $0,32 \mathrm{~mm}$, largura $0,1 \mathrm{~mm}$; largura do labro $0,58 \mathrm{~mm}$, placa labral sub-retangular, lisa, sem rúgulas, os lados convergentes, o ápice em arco rebaixado, comprimento $0,23 \mathrm{~mm}$, largura $0,38 \mathrm{~mm}$; escapo $0,46: 0,14 \mathrm{~mm}$; os três primeiros flagelômeros $0,13: 0,09: 0,1 \mathrm{~mm}, \varnothing$ do terceiro $0,14 \mathrm{~mm}, \varnothing$ máximo $0,16 \mathrm{~mm}$; flagelo e pedicelo juntos $1,48 \mathrm{~mm}$. Com oito hâmulos; fêmur médio com ângulo bem marcado, agudo, com o vértice em ponta fina; basitarso médio duas até três vezes mais longo que largo $(0,5: 0,2 \mathrm{~mm})$. Área basal do propódeo triangular, pequena, indistintamente delimitada, com rúgulas fortes, subparalelas; T2 com fóveas laterais rasas, pouco evidentes $(0,3: 0,1 \mathrm{~mm})$; placa pigidial rebordada, com rúgulas transversais.

Macho desconhecido.

Comentário. Semelhante a P. minutus Schlindwein \& Moure, 1998, mas difere pelo tamanho maior; olhos subparalelos; placa labral subretangular, mais larga que longa; propódeo densamente pontuado até a área basal; pontuação no mesoscuto menos densa; intervalos entre os pontos lisos e brilhantes na metade inferior da face; T2 com as fóveas laterais rasas, pouco evidentes.

Distribuição geográfica. PARAGUAI.

\section{Panurgillus pauloensis (Friese, 1916) comb.n.}

Panurginus pauloensis Friese, 1916: 171.

Holótipo fêmea (único exemplar). No MNHU. Etiquetas: [Brasil, Campinas, 15.3.1904, sem coletor]; [Type] (vermelho); [Panurginus pauloensis Fr. 1915 Friese det.]; [Zool. Mus. Berlin].

Diagnose. Intervalos entre os pontos na cabeça sem retículo, brilhantes; tíbias anteriores e médias com uma mancha amarela na base; lado ventral do mesepisterno 
com pêlos em gancho; 7 hâmulos; a fóvea facial rasa, oval; área basal do propódeo com limites indefinidos, apenas com uma curta carena média e algumas carenas fracas laterais.

Holótipo, fêmea. Comprimento total aproximado $5,3 \mathrm{~mm}$; asa anterior 4,24 $\mathrm{mm}$; largura da cabeça $1,6 \mathrm{~mm}$; comprimento da cabeça $1,34 \mathrm{~mm}$; largura do metasoma $2,3 \mathrm{~mm}$.

Tegumento preto; mandíbulas castanhas na metada apical; flagelo ocre por baixo; tégulas translúcidas; asas subhialinas com as veias e pterostigma castanhoclaros; tíbias anteriores e médias com uma mancha amarela na base. Depressões marginais dos tergos pouco translúcidas.

Pilosidade esbranquiçada, esparsa; na cabeça até $0,2 \mathrm{~mm}$; pêlos no escapo até $0,12 \mathrm{~mm}$. No mesoscuto densa, até $0,1 \mathrm{~mm}$; plumosa no pronoto; no metanoto e nos flancos dos mesepisternos até $0,2 \mathrm{~mm}$; lado ventral dos mesepisternos com pêlos em gancho; escopa branca com cerdas não plumosas, esparsas, comprimento $0,46 \mathrm{~mm}$. Plumosa e ereta na área basal do propódeo (até $0,12 \mathrm{~mm}$ ); T5 com cerdas amarelas (cerca de $0,25 \mathrm{~mm}$ ) e com curta franja apical.

Pontuação na cabeça profunda, relativamente grossa e esparsa $(0,03 \mathrm{~mm}$, 1-2dp), os intervalos lisos e com micropontos intercalados, às vezes com retículo muito fino, brilhante; na fronte um pouco mais densa, no clípeo e nas áreas paroculares inferiores um pouco mais grossa; uma área lisa acima dos alvéolos e do lado dos océlos laterais. No mesoscuto esparsa e fina (cerca de $0,02 \mathrm{~mm}, \geq 2 \mathrm{dp}$ ), os intervalos reticulados; no escutelo mais grossa; no metanoto mais densa; nos mesepisternos adensado para cima, os intervalos reticulados. Na face posterior do propódeo fina e fraca, faltando junto a área basal, com retículo forte; no T1-T4 fina $(<0,02 \mathrm{~mm}$; cerca de $1 \mathrm{dp})$, mais esparsa em direção a depressão marginal; no T1 um pouco mais esparsa; no T5 mais grossa e muito esparsa; intervalos de todos os tergos fracamente reticulados, no T1 quase lisos; depressões marginais reticuladas.

Comprimento do olho $0,98 \mathrm{~mm}$, largura $0,52 \mathrm{~mm}$; distâncias interorbitais: superior $1,04 \mathrm{~mm}$, média $1 \mathrm{~mm}$, inferior $0,96 \mathrm{~mm}$; distância interalveolar $0,26 \mathrm{~mm}$; alveolorbital $0,26 \mathrm{~mm}$; alveolocelar $0,44 \mathrm{~mm}$; $\varnothing$ alvéolo $0,13 \mathrm{~mm}$; interocelar 0,24 $\mathrm{mm}$; ocelorbital $0,32 \mathrm{~mm} ; \varnothing$ ocelo médio $0,13 \mathrm{~mm}$; comprimento das suturas subantenais: externa $0,36 \mathrm{~mm}$, interna $0,26 \mathrm{~mm}$, largura máxima da área subantenal $0,14 \mathrm{~mm}$; comprimento do clípeo $0,42 \mathrm{~mm}$, largura $0,96 \mathrm{~mm}$; clipeocelar $0,7 \mathrm{~mm}$; linha frontal sulciforme, inconspícua no ocelo médio; sulco longitudinal acima do ocelo médio na área interocelar; fóvea facial oval, um pouco alargada em cima, muito rasa, sem pêlos, comprimento $0,22 \mathrm{~mm}$, largura $0,1 \mathrm{~mm}$; largura do labro 0,48 $\mathrm{mm}$, placa labral curta e larga, as margens laterais convergentes, margem anterior em arco rebaixado, comprimento $0,16 \mathrm{~mm}$, largura $0,3 \mathrm{~mm}$; escapo $0,42: 0,12 \mathrm{~mm}$; os três primeiros flagelômeros $0,12: 0,08: 0,09 \mathrm{~mm}, \varnothing$ do terceiro $0,12 \mathrm{~mm}$, maior $\varnothing 0,15 \mathrm{~mm}$; flagelo e pedicelo juntos cerca de $1,14 \mathrm{~mm}$. Sete hâmulos; fêmur médio sem ângulo; basitarso médio duas até três vezes mais longo que largo $(0,52: 0,18$ $\mathrm{mm}$ ); área basal do propódeo com limites indefinidos, apenas com uma curta carena média e algumas carenas obsoletas laterais; $\mathrm{T} 2$ com fóveas laterais pouco evidentes, rasas $(0,24: 0,12 \mathrm{~mm})$; placa pigidial rebordada, com estrias transversais.

Macho desconhecido. 
Comentário. Semelhante à $P$. harterae, difere pela mancha amarela nas tíbias médias, sete hâmulos e pela ausência de retículo forte no clípeo; difere de P. harterae, $P$. flavitarsis e $P$. plumosulus pela presença de pêlos em gancho no lado ventral do mesepisterno.

Distribuição geográfica. BRASIL: São Paulo.

\section{Panurgillus saltensis (Friese, 1908) comb.n.}

Panurginus saltensis Friese, 1908: 26.

Lectótipo, fêmea, e paralectótipo macho no MNHU. Etiquetas na fêmea e no macho: [Argentina, Salta, 1200, 3.1905, Steinbach]; [Type] (vermelho); [Panurginus saltensis Fr. 1907 Friese det.]; [Zool. Mus. Berlin].

Diagnose. Fêmea com uma mancha amarelo-clara, oval, no disco do clípeo; lóbulos pronotais pretos; pêlos compridos no mesoscuto e na cabeça; lado ventral do mesepisterno sem pêlos em gancho; área basal do propódeo sem pêlos, somente com uma carena média evidente e rúgulas laterais inconspícuas; placa labral curta, com os lados fortemente divergentes; fóvea tentorial estreitada para baixo, com o bordo parocular elevado, liso brilhante, sem pontos (na fêmea e no macho). Macho com o clípeo amarelo menos os flancos; pilosidade comprida no mesoscuto, na face e no escapo; E4 com alguns pêlos quadriramosos no meio, característicos.

Lectótipo, fêmea. Comprimento total aproximado $6,7 \mathrm{~mm}$; asa anterior 5,1 $\mathrm{mm}$; largura da cabeça $1,92 \mathrm{~mm}$; comprimento da cabeça $1,66 \mathrm{~mm}$; largura do metasoma 2,06 mm.

Tegumento preto; uma mancha amarelo-clara, oval, no disco do clípeo, comprimento $0,44 \mathrm{~mm}$, largura $0,28 \mathrm{~mm}$, não chegando até o bordo anterior; metade basal da placa labral castanho-clara; flagelo amarelo pálido por baixo. Lóbulos pronotais pretos; tégula translúcida; asas levemente fuscas, com veias e pterostigma castanho-claros; pernas castanho-escuras, base das tíbias anteriores e médias com uma mancha translúcida. Metasoma castanho-escuro; depressões marginais dos tergos pouco translúcidas.

Pilosidade amarelada até esbranquiçada; na cabeça até $0,3 \mathrm{~mm}$, plumosa, mais curta na fronte; pêlos no escapo até $0,32 \mathrm{~mm}$. No mesoscuto até $0,22 \mathrm{~mm}$; no escutelo cerca de $0,4 \mathrm{~mm}$; relativamente comprida também nos mesepisternos; lado ventral do mesepisterno sem pêlos em gancho; escopa com cerdas pouco plumosas, até $0,5 \mathrm{~mm}$. Comprida nos flancos do propódeo; área basal sem pêlos; cerdas no T5 cerca de $0,4 \mathrm{~mm}$.

Pontuação densa na fronte ( $<1 \mathrm{dp}, 0,02-0,03 \mathrm{~mm}$ ) mais grossa no clípeo; com $\varnothing$ variados nas áreas supraclipeal, paroculares e subantenais; com micropontos intercalados em toda face; clípeo predominantemente liso-brilhante, muito finamente reticulado perto da sutura epistomal; áreas paroculares inferiores, subantenais e supraclipeal lisas; bordo parocular liso-brilhante, sem pontos; retículo forte acima dos alvéolos; na área ocelorbital mais esparsa (cerca de $2 \mathrm{dp}$ ) os intervalos reticulados; nas genas mais densa, os intervalos fracamente reticulados, quase lisos. No mesoscuto fina e densa (cerca de $0,02 \mathrm{~mm}, \geq 1 \mathrm{dp}$, alguns intervalos menores), os intervalos reticulados; no escutelo e metanoto como no mesoscuto, os pontos mais 
profundos, no metanoto o retículo muito forte; os mesepisternos fortemente reticulados. Propódeo com retículo evidente, hexagonal, porém um pouco brilhante junto à área basal, face posterior com pontuação fina; nos tergos fina (0,02 mm, 1-2dp), ficando mais esparsa próximo das depressões marginais, os intervalos finamente reticulados; no T5 mais grossa e mais esparsa; depressões marginais nos tergos micro-reticulados.

Comprimento do olho $1,02 \mathrm{~mm}$, largura $0,58 \mathrm{~mm}$; olhos paralelos, distâncias interorbitais: superior $1,26 \mathrm{~mm}$, média $1,26 \mathrm{~mm}$, inferior $1,26 \mathrm{~mm}$; distância interalveolar $0,32 \mathrm{~mm}$; alveolorbital $0,32 \mathrm{~mm}$; alveolocelar $0,54 \mathrm{~mm}$; $\varnothing$ alvéolo $0,14 \mathrm{~mm}$; interocelar $0,24 \mathrm{~mm}$; ocelorbital $0,42 \mathrm{~mm}$; $\varnothing$ ocelo médio $0,15 \mathrm{~mm}$; comprimento das suturas subantenais: externa $0,42 \mathrm{~mm}$, interna $0,32 \mathrm{~mm}$, largura da área subantenal $0,22 \mathrm{~mm}$; comprimento do clípeo $0,52 \mathrm{~mm}$, largura cerca de 1,2 $\mathrm{mm}$; clipeocelar $0,84 \mathrm{~mm}$; fóvea tentorial estreitada para baixo, com o bordo parocular elevado; linha frontal com carena pouco evidente entre os alvéolos, sulciforme até o ocelo médio; fóvea facial bem marcada, lisa, opaca, comprimento $0,3 \mathrm{~mm}$, largura $0,07 \mathrm{~mm}$; largura do labro $0,6 \mathrm{~mm}$, placa labral trapezóide com os cantos arredondados, lisa e deprimida para o meio, comprimento $0,24 \mathrm{~mm}$, largura na base $0,44 \mathrm{~mm}$, no ápice $0,22 \mathrm{~mm}$; escapo $0,5: 0,15 \mathrm{~mm}$; flagelo clavado, os três primeiros flagelômeros $0,19: 0,1: 0,1 \mathrm{~mm}, \varnothing$ do terceiro $0,15 \mathrm{~mm}$, maior $\varnothing 0,17 \mathrm{~mm}$; flagelo e pedicelo juntos cerca de $1,6 \mathrm{~mm}$. Oito hâmulos; fêmur médio com ângulo obtuso; comprimento do basitarso médio $0,66 \mathrm{~mm}$, largura $0,28 \mathrm{~mm}$. Área basal do propódeo semilunar, somente com uma carena média forte e rúgulas laterais inconspícuas; T2 com fóveas laterais rasas (cerca de 0,32:0,1 mm).

Paralectótipo, macho. Tamanho: comprimento total aproximado $6 \mathrm{~mm}$; asa anterior 4,8 mm; largura da cabeça $2 \mathrm{~mm}$; comprimento da cabeça $1,7 \mathrm{~mm}$; largura do metasoma $1,86 \mathrm{~mm}$.

Tegumento preto; o clípeo amarelo menos os cantos laterais e duas manchinhas pretas, simétricas proximas às fóveas tentoriais anteriores; flagelo castanhoclaro por baixo. Tégulas translúcidas; asas levemente fuscas, veias e pterostigma castanho-claros; pernas castanhas, face anterior das tíbias anteriores amarela, base das tíbias médias com uma mancha amarela. Metasoma castanho-escuro; depressões marginais dos tergos pouco transparentes.

Pilosidade esbranquiçada; na metade inferior da face e no vértice cerca de $0,3 \mathrm{~mm}$, plumosa; muito comprida e plumosa no escapo $(0,38 \mathrm{~mm})$. No mesoscuto, escutelo, metanoto e nos mesepisternos comprida e plumosa (cerca de $0,4 \mathrm{~mm}$ ). Nos flancos do propódeo um pouco mais curta; área basal do propódeo sem pêlos; E4 com alguns pêlos quadriramosos no meio, direcionados para trás, característicos.

Pontuação parecida à da fêmea; densa na fronte e nas áreas paroculares ( $\leq 1 \mathrm{dp}$ ), no clípeo, nas áreas subantenais e supraclipeal um pouco menos densa; mais grossa no clípeo e nas áreas paroculares; os intervalos com micropontos intercalados e com retículo fraco, brilhante em toda face, quase liso na área supraclipeal, bordo parocular liso-brilhante, sem pontos; na área ocelorbital mais esparsa (1-2dp), nas genas $1-2 \mathrm{dp}, \varnothing 0,02 \mathrm{~mm}$, os intervalos lisos. No mesoscuto fina $(0,02 \mathrm{~mm})$, os intervalos 1-2 dp, com retículo muito fraco, um pouco brilhante; no escutelo como no mesoscuto; no metanoto um pouco mais densa (cerca de 1dp) e com retículo mais 
forte. Propódeo com retículo evidente, hexagonal junto à área basal, face posterior com pontuação fina (como na fêmea); nos tergos fina $(0,02 \mathrm{~mm}, 1-2 \mathrm{dp})$, ficando mais esparsa próximo das depressões marginais, os intervalos finamente reticulados; no T6 mais grossa; depressões marginais finamente micro-reticuladas.

Comprimento do olho $1,04 \mathrm{~mm}$, largura $0,64 \mathrm{~mm}$; olhos convergentes para baixo, distâncias interorbitais: superior $1,3 \mathrm{~mm}$, média $1,2 \mathrm{~mm}$, inferior $1,14 \mathrm{~mm}$; distância interalveolar $0,32 \mathrm{~mm}$; alveolorbital $0,28 \mathrm{~mm}$; alveolocelar $0,5 \mathrm{~mm}$; $\varnothing$ alvéolo $0,15 \mathrm{~mm}$; interocelar $0,28 \mathrm{~mm}$; ocelorbital $0,42 \mathrm{~mm}$; $\varnothing$ ocelo médio 0,18 $\mathrm{mm}$; comprimento das suturas subantenais, externa $0,44 \mathrm{~mm}$, interna $0,3 \mathrm{~mm}$, largura da área subantenal $0,19 \mathrm{~mm}$; comprimento do clípeo $0,54 \mathrm{~mm}$, largura cerca de $1,24 \mathrm{~mm}$; clipeocelar $0,84 \mathrm{~mm}$; fóvea tentorial estreitada para baixo com o bordo parocular elevado; linha frontal careniforme, interrompida, uma parte interalveolar e a outra muito curta em frente ao ocelo médio; fóvea facial bem marcada, opaca, comprimento $0,26 \mathrm{~mm}$, largura $0,09 \mathrm{~mm}$; largura do labro $0,6 \mathrm{~mm}$; placa labral lisa, quase em semicírculo, um pouco deprimida no meio, comprimento $0,26 \mathrm{~mm}$, largura na base $0,4 \mathrm{~mm}$; escapo $0,44: 0,16 \mathrm{~mm}$; os três primeiros flagelômeros $0,18: 0,1: 0,14$ $\mathrm{mm}, \varnothing$ do terceiro $0,16 \mathrm{~mm}$, maior $\varnothing 0,18 \mathrm{~mm}$; flagelo e pedicelo juntos $2,2 \mathrm{~mm}$. Oito hâmulos; basitarso médio cerca de quatro vezes mais longo que largo $(0,6: 0,14$ $\mathrm{mm})$. Área basal do propódeo semilunar, a carena média mais forte, algumas carenas laterais fracas e curtas; T2 com fóveas laterais rasas $(0,26: 0,08 \mathrm{~mm})$.

Comentário. Espécie característica pelas fóveas tentoriais estreitadas para baixo, com o bordo parocular elevado.

Distribuição geográfica. ARGENTINA: Salta.

\section{Panurgillus solani (Ducke, 1912) comb.n.}

Panurginus solani Ducke, 1912: 87.

Lectótipo, fêmea, e paralectótipo, macho no MNHU. Etiquetas na fêmea e no macho: [Rio de Janeiro, Tijuca 500m, XI.1911, Ducke; [Type] (vermelho); [Panurginus solani Ducke typ]; [Panurginus solani Ducke, 1909 (?) Friese det.]; [Zool. Mus. Berlin].

Diagnose. Fêmea com a área basal do propódeo posteriormente cercada por uma faixa liso-brilhante sem pontos, maior que o comprimento da área basal; área basal sem pêlos; tergos lisos e brilhantes entre os pontos, inclusive nas depressões marginais; pontuação muito esparsa em T1-T4 ( $>3 \mathrm{dp}$ ) e muito fina; lado ventral do mesepisterno sem pêlos em gancho. No macho a face inteiramente preta; cabeça com pontuação densa, os intervalos liso-brilhantes; placa labral retangular, área basal do propódeo posteriormente cercada por uma faixa com retículo grande.

Lectótipo, fêmea. Comprimento total aproximado 5,1 mm; asa anterior 4,6 $\mathrm{mm}$; largura da cabeça $1,68 \mathrm{~mm}$; comprimento da cabeça $1,38 \mathrm{~mm}$; largura do metasoma $1,76 \mathrm{~mm}$.

Tegumento preto; antena inteiramente preta. Tégulas translúcidas; asas levemente fuscas com veias e pterostigma castanhos; tarsos castanho-claros; base das tíbias anteriores e médias sem manchas amarelas, porém com tegumento translúcido. Depressões marginais dos tergos escuras. 
Pilosidade amarelada, esparsa; na face cerca de $0,14 \mathrm{~mm}$, com algumas cerdas compridas intercaladas, não plumosas (até $0,26 \mathrm{~mm}$ ); no vértice muito curta (cerca de $0,06 \mathrm{~mm}$ ), nas genas um pouco mais comprida; pêlos no escapo cerca de $0,06 \mathrm{~mm}$ (poucos até $0,1 \mathrm{~mm}$ ). No mesoscuto muito curta (até $0,06 \mathrm{~mm}$ ); no lado dorsal do pronoto como no mesoscuto, nos lóbulos um pouco mais comprida e finamente plumosa; no metanoto até $0,22 \mathrm{~mm}$; nos flancos dos mesepisternos mais curta; lado ventral do mesepisterno sem pêlos em gancho; escopa com cerdas brancas, não plumosas, cerca de $0,4 \mathrm{~mm}$. Nos flancos do propódeo mais curta; área basal do propódeo sem pêlos; cerdas no T5 até $0,4 \mathrm{~mm}$ e com curta franja apical.

Pontuação relativamente grossa e densa na fronte, áreas subantenais, paroculares, vértice e genas $(\varnothing 0,03-0,04 \mathrm{~mm},<1 \mathrm{dp})$; um pouco mais grossa e menos densa no clípeo e na área supraclipeal; mais esparsa na área ocelorbital (1-2dp) e com uma área sem pontos ao lado dos ocelos laterais, do tamanho do ocelo; todos os intervalos na cabeça lisos e brilhantes, com micropontos intercalados, $\varnothing$ até 0,03 $\mathrm{mm}, 1-2 \mathrm{dp}$. Intervalos no mesoscuto 1-2dp, reticulados; no escutelo e metanoto com vários $\varnothing(0,02-0,05 \mathrm{~mm})$, os intervalos lisos e brilhantes e com micropontos intercalados; no escutelo esparsa (até $4 \mathrm{dp}$ ), no metanoto densa ( $<1 \mathrm{dp})$; nos flancos dos mesepisternos grossa, um pouco adensada para cima ( $\geq 1 \mathrm{dp})$, com os intervalos lisos, embaixo esparsa e com retículo fraco. O propódeo muito característico: sem retículo, pontuação densa e grossa no flanco posterior, esta área pontuada separada da área basal por uma larga faixa acuminada, liso-brilhante, sem pontos, mais longa que o metanoto; todos os tergos lisos e brilhantes, inclusive as depressões marginais; T1 quase inteiramente liso, somente com alguns micropontos; em T2-T4 muito fina $(<0,02 \mathrm{~mm})$ e muito esparsa (em geral $>4 \mathrm{dp}$ ), um pouco mais densa na base; no T5 mais grossa e densa.

Comprimento do olho $0,96 \mathrm{~mm}$, largura $0,5 \mathrm{~mm}$; distâncias interorbitais: superior $1,12 \mathrm{~mm}$, média $1,08 \mathrm{~mm}$, inferior $0,98 \mathrm{~mm}$; distância interalveolar 0,26 $\mathrm{mm}$; alveolorbital $0,26 \mathrm{~mm}$; alveolocelar $0,46 \mathrm{~mm}$; $\varnothing$ alvéolo $0,14 \mathrm{~mm}$; interocelar $0,22 \mathrm{~mm}$; ocelorbital $0,34 \mathrm{~mm} ; \varnothing$ ocelo médio $0,16 \mathrm{~mm}$; comprimento das suturas subantenais: externa $0,38 \mathrm{~mm}$, interna $0,3 \mathrm{~mm}$, largura da área subantenal $0,14 \mathrm{~mm}$; comprimento do clípeo $0,42 \mathrm{~mm}$, largura $1,04 \mathrm{~mm}$; clipeocelar $0,76 \mathrm{~mm}$; linha frontal sulciforme entre os alvéolos, ausente na metade superior; fóvea facial bem marcada, lisa, estreita, um pouco alargado em cima, comprimento $0,4 \mathrm{~mm}$, largura $0,1 \mathrm{~mm}$; largura do labro $0,56 \mathrm{~mm}$, placa labral lisa, os lados convergentes, 0 ápice em linha reta, comprimento $0,14 \mathrm{~mm}$, largura $0,24 \mathrm{~mm}$; escapo $0,48: 0,12 \mathrm{~mm}$; flagelo ligeiramente clavado, os três primeiros flagelômeros $0,14: 0,09: 0,09 \mathrm{~mm}, \varnothing$ do terceiro $0,14 \mathrm{~mm}$, maior $\varnothing 0,16 \mathrm{~mm}$; flagelo e pedicelo juntos cerca de $1,44 \mathrm{~mm}$. Com 9-10 hâmulos; fêmur médio em curva contínua; basitarso médio duas vezes mais longo que largo, comprimento $0,48 \mathrm{~mm}$, largura $0,24 \mathrm{~mm}$. Área basal do propódeo triangular, sem delimitação posterior, carena média mais forte, as laterais subparalelas, curtas; T2 com fóveas laterais pouco evidentes, rasas $(0,24: 0,1 \mathrm{~mm})$.

Paralectótipo, macho. Comprimento total aproximado $5,8 \mathrm{~mm}$; asa anterior $4,8 \mathrm{~mm}$; largura da cabeça $1,58 \mathrm{~mm}$; comprimento da cabeça $1,3 \mathrm{~mm}$; largura do metasoma $1,4 \mathrm{~mm}$.

Tegumento preto; mandíbulas amarelas com exeção de uma mancha preta na base. Tégulas translúcidas; asas levemente esfumaçadas; veias e pterostigma 
castanhos; tarsos e tíbias amarelo-ocres, as outras partes das pernas castanhas. Depressões marginais dos tergos pouco transparentes.

Pilosidade amarelada, esparsa, rala; na metade inferior da face pouco plumosa, cerca de $0,14 \mathrm{~mm}$, algumas cerdas até $0,26 \mathrm{~mm}$; na metade superior e nas genas $0,06 \mathrm{~mm}$, no vértice alguns pêlos até $0,1 \mathrm{~mm}$; no escapo $0,06 \mathrm{~mm}$, alguns pêlos até $0,1 \mathrm{~mm}$. No mesoscuto até $0,06 \mathrm{~mm}$; no escutelo e nos flancos dos mesepisternos até $0,12 \mathrm{~mm}$; no metanoto e nos flancos do propódeo um pouco mais comprida, pouco plumosa. Área basal do propódeo sem pêlos.

Pontuação na cabeça relativamente grossa e densa (cerca de 0,04 mm, $\geq 1 / 2 \mathrm{dp}$ ), os intervalos liso-brilhantes; menos densa nas áreas paroculares e ocelorbitais (cerca de $1 \mathrm{dp})$. No mesoscuto forte e densa $(0,02 \mathrm{~mm}, \leq 1 \mathrm{dp})$, os intervalos fracamente reticulados; no escutelo mais grossa, os intervalos lisos; no metanoto muito densa $(<1 / 2 \mathrm{dp})$; nos mesepisternos grossa e esparsa embaixo $(0,04 \mathrm{~mm}$, até $3 \mathrm{dp}$ ), adensada para cima, os intervalos lisos e brilhantes; nos metepisternos mais fina e muito densa $(<1 / 2 \mathrm{dp})$. Propódeo nos flancos fina e muito densa $(<1 / 2 \mathrm{dp})$; no lado posterior densa e grossa como na fêmea, esta área pontuada separada da área basal por uma faixa larga, um pouco mais curta que o metanoto, os intervalos fracamente reticulados, sem pontos; nos tergos semelhante à fêmea, porém mais grossa; muito esparsa ( $>4 \mathrm{dp}$ ) e lisa; pontuação densa $(\leq 1 \mathrm{dp})$ restrita a áreas pequenas nos flancos do T1-T3; depressões marginais lisas e brilhantes como na fêmea.

Comprimento do olho $1 \mathrm{~mm}$, largura $0,52 \mathrm{~mm}$; olhos convergentes para baixo, distâncias interorbitais: superior $1,06 \mathrm{~mm}$, média $0,9 \mathrm{~mm}$, inferior $0,82 \mathrm{~mm}$; distância interalveolar $0,24 \mathrm{~mm}$; alveolorbital $0,2 \mathrm{~mm}$; alveolocelar $0,46 \mathrm{~mm} ; \varnothing$ alvéolo $0,1 \mathrm{~mm}$; interocelar $0,18 \mathrm{~mm}$; ocelorbital $0,32 \mathrm{~mm}$; $\varnothing$ ocelo médio 0,18 $\mathrm{mm}$; suturas subantenais: externa $0,32 \mathrm{~mm}$, interna $0,24 \mathrm{~mm}$, largura máxima da área subantenal no meio $0,09 \mathrm{~mm}$, as duas suturas recurvadas, a externa para fora, a interna para o meio; comprimento do clípeo $0,42 \mathrm{~mm}$, largura cerca de $0,86 \mathrm{~mm}$; clipeocelar $0,7 \mathrm{~mm}$; linha frontal como na fêmea; fóvea facial lisa, bem marcada, comprimento $0,28 \mathrm{~mm}$, largura $0,1 \mathrm{~mm}$; largura do labro $0,44 \mathrm{~mm}$; placa labral lisa, retangular, os lados subparalelos, o ápice em linha reta, comprimento 0,14 mm, largura $0,28 \mathrm{~mm}$; escapo $0,32: 0,13 \mathrm{~mm}$; os três primeiros flagelômeros $0,1: 0,08: 0,1$ $\mathrm{mm}, \varnothing$ do terceiro $0,15 \mathrm{~mm}$, maior $\varnothing 0,17 \mathrm{~mm}$; flagelo e pedicelo juntos cerca de 1,5 mm. Com 8-9 hâmulos; basitarso médio três a quatro vezes mais longo que largo $(0,48: 0,14 \mathrm{~mm})$. Área basal do propódeo semilunar, com carenas curtas paralelas; $\mathrm{T} 2$ com fóveas laterais pequenas, rasas, ovais, com pontos $(0,1: 0,06 \mathrm{~mm})$.

Comentário. Espécie característica pelo propódeo com área lisa e brilhante, sem pontos, bem demarcada atrás da área basal (esta área no macho reticulada), pela ausência de pêlos na área basal e pelo tegumento liso nos tergos.

Distribuição geográfica. BRASIL: Rio de Janeiro.

\section{Panurgillus steinbachi (Friese, 1916) comb.n.}

Panurginus steinbachi Friese, 1916: 170.

Lectótipo, macho, e um paralectótipo, macho no MNHU. Etiquetas no Lectótipo: [Argentina, Salta, 1200, 3.1905, Steinbach]; [Type] (vermelho); [Panur-

Revta bras. Zool. 16 (Supl. 1): 113 - 133, 1999 
ginus steinbachi Fr. 1915 Friese det.]; [Zool. Mus. Berlin]. O paralectótipo com os mesmos dados do lectótipo, porém sem a etiqueta "Type".

Diagnose. Macho com o clípeo amarelo menos uma faixa preta, fina, no bordo anterior, alargada nos flancos; cantos inferiores das áreas paroculares com pequena mancha amarela; mandíbulas amarelas com exceção de uma mancha preta na base; lóbulos pronotais amarelos; intervalos entre os pontos na cabeça liso-brilhantes com exceção de uma faixa característica, inchada, mate, fortemente reticulada, quase sem pontos acima das fóveas faciais até o ocelo médio; face inchada entre os olhos.

Lectótipo, macho. Tamanho: comprimento total aproximado $4,8 \mathrm{~mm}$; asa anterior 3,88 mm; largura da cabeça $1,34 \mathrm{~mm}$; comprimento da cabeça $1,38 \mathrm{~mm}$; largura do metasoma $1,26 \mathrm{~mm}$.

Tegumento preto; clípeo amarelo com exceção de uma faixa preta fina no bordo anterior, alargada nos flancos, sem manchas pretas perto das fóveas tentoriais anteriores (o paralectótipo com pequenas manchas pretas); cantos inferiores das áreas paroculares com pequena mancha amarela; mandíbulas amarelas menos uma mancha preta na base; antenas castanhas, o flagelo amarelo por baixo. Lóbulos pronotais amarelos; tégulas translúcidas; asas levemente fuscas, veias e pterostigma castanhos; pernas castanho-escuras com a extremidade apical dos fêmures com uma pequena mancha amarela, tíbias anteriores com uma faixa amarela na frente, tíbias médias com uma mancha amarela na base, tíbias posteriores com a metade basal amarela; tarsos dos três pares amarelos. Metasoma castanho-escuro, as depressões marginais dos tergos transparentes.

Pilosidade esbranquiçada, esparsa, rala; na cabeça curta $(0,08 \mathrm{~mm})$; no escapo até $0,1 \mathrm{~mm}$. No mesoscuto e escutelo curta $(0,06 \mathrm{~mm})$; no metanoto mais comprida e plumosa; nos mesepisternos cerca de $0,14 \mathrm{~mm}$. Nos flancos do propódeo cerca de $0,14 \mathrm{~mm}$; na área basal pouco evidente, curta $(0,06 \mathrm{~mm})$.

Pontuação densa na fronte e na área supraclipeal ( $\leq 1 \mathrm{dp}, 0,02-0,03 \mathrm{~mm}$ ); no clípeo mais grossa, cerca de $1 \mathrm{dp}$; um pouco mais esparsa nas áreas subantenais e paroculares inferiores; no vértice cerca de $1 \mathrm{dp}$; nas genas fina $(<0,02 \mathrm{~mm}, 2 \mathrm{dp})$; intervalos com micropontos intercalados em toda cabeça; os intervalos liso-brilhantes com exceção de uma faixa característica, inchada, mate, fortemente reticulada quase sem pontos acima das fóveas faciais até o ocelo médio. No mesoscuto profunda, $0,02 \mathrm{~mm}, 1 \mathrm{dp}$, os intervalos lisos e brilhantes; no escutelo um pouco mais grossa e um pouco mais esparsa, os intervalos lisos e brilhantes e com micropontos intercalados; no metanoto densa e grossa $(<1 / 2 \mathrm{dp}, \varnothing 0,03 \mathrm{~mm})$ os intervalos lisos; nos mesepisternos densa e grossa, os intervalos liso-brilhantes anteriormente, reticulados para trás. Nos flancos do propódeo muito densa, os intervalos formando rúgulas e na face posterior densa, quase sem pontos perto da área basal, porém com retículo; nos tergos densa e profunda ( $\leq 1 \mathrm{dp}, 0,02 \mathrm{~mm})$, adensada na base, os intervalos lisos; depressão marginal dos tergos micro-reticuladas.

Face inchada entre os olhos, fóveas faciais somente visíveis do lado; ocelo médio direcionado para frente, os ocelos laterais para cima; frente inchada acima das fóveas faciais com o tegumento fortemente reticulado; comprimento do olho 
$0,74 \mathrm{~mm}$, largura $0,42 \mathrm{~mm}$; olhos convergentes para baixo, distâncias interorbitais: superior $1,08 \mathrm{~mm}$, média $0,9 \mathrm{~mm}$, inferior $0,78 \mathrm{~mm}$; distância interalveolar 0,26 $\mathrm{mm}$; alveolorbital $0,26 \mathrm{~mm}$; alveolocelar $0,44 \mathrm{~mm}$; $\varnothing$ alvéolo $0,13 \mathrm{~mm}$; interocelar $0,26 \mathrm{~mm}$; ocelorbital $0,44 \mathrm{~mm} ; \varnothing$ ocelo médio $0,09 \mathrm{~mm}$; área subantenal mais larga na metade superior, suturas subantenais convergentes para baixo, a interna $(0,34$ $\mathrm{mm})$ quase tão longa como a externa $(0,36 \mathrm{~mm})$, largura máxima da área subantenal $0,12 \mathrm{~mm}$; comprimento do clípeo $0,42 \mathrm{~mm}$, largura cerca de $0,7 \mathrm{~mm}$; clipeocelar $0,72 \mathrm{~mm}$; linha frontal pouco evidente; fóvea facial lisa, mate, comprimento 0,20 $\mathrm{mm}$, largura $0,06 \mathrm{~mm}$; largura do labro $0,38 \mathrm{~mm}$; placa labral lisa, os lados convergentes, o ápice em arco rebaixado, comprimento $0,2 \mathrm{~mm}$, largura $0,24 \mathrm{~mm}$; escapo $0,36: 0,15 \mathrm{~mm}$; os três primeiros flagelômeros $0,1: 0,1: 0,13 \mathrm{~mm}, \varnothing$ do terceiro $0,15 \mathrm{~mm}$, maior $\varnothing 0,17 \mathrm{~mm}$; flagelo e pedicelo juntos $1,84 \mathrm{~mm}$. Com oito hâmulos. Área basal do propódeo semilunar, com carenas relativamente fortes, subparalelas; T2 com fóveas laterais pouco evidentes, rasas $(0,09: 0,06 \mathrm{~mm})$.

Fêmea não conhecida.

Comentário. Macho característico pela face inchada entre os olhos, pelas fóveas faciais direcionadas para o lado e pelas áreas fortemente reticuladas acima das fóveas laterais, o restante da cabeça liso.

Distribuição geográfica. ARGENTINA: Salta.

\section{Cephalurgus laticeps (Friese, 1916) comb.n.}

Panurginus laticeps Friese, 1916: 169.

Três machos no MNHU. Lectótipo com as etiquetas: [Argentina, Salta 2500, 3.1905, Steinbach]; [Type] vermelha; [Panurginus laticeps Fr., 1915 Friese det.]; [Zool. Mus. Berlin]. Os outros dois machos, considerados paralectótipos, têm a mesma data e coletor, porém Salta 1200 e sem etiqueta "Type" em vermelho.

Abaixo uma redescrição de Cephalurgus laticeps (Friese, 1916).

Macho. Comprimento total aproximado $5,25 \mathrm{~mm}$, da asa anterior um pouco estragada no ápice 4,4 $\mathrm{mm}$; largura da cabeça 1,8 $\mathrm{mm}$ e do T2 1,6 $\mathrm{mm}$.

Preto, o abdome pardo-escuro com as depressões marginais pálido-translúcidas. Com os seguintes desenhos amarelos, o amarelo um pouco pálido: o clípeo em forma de chapéu, com as dobras ventrais inferiores pretas e um ponto preto a cada lado pouco abaixo das fóveas tentoriais; nas paroculares inferiores em arco superiormente sobrepassando um pouco a tangente sobre a epistomal; aproximadamente os dois terços basais das mandíbulas; uma faixa basal um pouco irregular na placa labral; os lobos pronotais; o ápice dos fêmures e largamente as tíbias e tarsos de todos os pares, com uma estria pardo-clara na face externa das tíbias médias e posteriores. As tégulas amarelo-translúcidas; as asas hialinas ligeiramente irisadas, a venação mélea e o estigma mais amarelado. As depressões marginais dos tergos e esternos pálido-translúcidas.

A pilosidade branca, curta, esparsa na face, mesoscuto e escutelo; um pouco mais desenvolvida nas genas, metanoto, mesepisternos e flancos do propódeo; nos tergos baixa e decumbente, mais evidente nos lados de T4-6 e nos esternos; nas pernas um pouco mais longa e bastante esparsa. 
Pontuação fina e densa na fronte (1dp), mais esparsa nas paroculares, na supraclipeal e no clípeo; no vértice um pouco mais grossa e os intervalos lisos cerca de $2 \mathrm{dp}$. No mesoscuto e escutelo um pouco mais fina, os intervalos lisos de $2 \mathrm{dp}$; no metanoto e nos mesepisternos um pouco mais forte e mais densa, com a escroba mais deprimida; nos metepisternos fina e os intervalos um pouco reticulados. Nos flancos do propódeo fina e os intervalos reticulados; nos tergos mais fina e mais densa que no mesoscuto, mais fraca nas depressões marginais, estas com vestígios de canaliculado transversal.

A cabeça bastante volumosa, mais larga que longa $(1,80: 1,35 \mathrm{~mm})$; olhos (1,0:0,5 mm) mais divergentes para baixo; área malar linear; genas de perfil quase como os olhos; interorbitais maiores que o comprimento do olho $(1,2: 1,25: 1,3 \mathrm{~mm})$; clípeo em 'chapéu', fortemente recortado para alojamento do labro com as pontas do recorte fortes e um pouco divergentes, comprimento do clípeo desde o bordo do recorte dois terços da sua distância ao ocelo médio $(0,45 / 0,6 \mathrm{~mm})$; parte superior da área supraclipeal um pouco inchada e elevada abrindo-se em Y para encaixe do ocelo médio; os alvéolos deprimidos e as fóveas faciais pequenas $(0,24: 0,08 \mathrm{~mm})$; áreas subantenais pequenas, pouco distintas, concolores; áreas ocelorbitais deprimidas e ocelos laterais inclinados para as mesmas, a interocelar menor que a ocelocular e menos de dois diâmetros de ocelo $(0,24: 0,35: 0,15 \mathrm{~mm})$; bordo occipital largamente arredondado. Os palpos labiais com o artículo basal tão longo como os três seguintes juntos; palpos maxilares de seis artículos bastante iguais entre si, atingido a ponta da gálea; labro curto com forte franja marginal, placa labral deprimida ao longo do meio e com o bordo em arco rebaixado; mandíbulas longas em ponta, sem dentes e com forte franja de pêlos plumosos curvos no bordo inferior. Escapo relativamente curto, pouco mais longo que duas vezes seu diâmetro (0,35:0,14 mm), o pedicelo globoso, flagelômero 1 obcônico, quase tão longo como seu diâmetro apical, o restante do flagelo com os flagelômeros mais curtos que os próprios diâmetros, um pouco amarelados inferiormente, sem formar clava. Área basal do propódeo em semilua, um pouco em cúspide atrás, com umas poucas carenas fortes irregulares.

Comentário. Os machos entram em Cephalurgus pelo formato característico da cabeça e dos esternos: cabeça muito larga (mais larga que o tórax); olhos levemente divergentes embaixo; placa labral pouco elevada, margem anterior não claramente delimitada, com uma franja de pêlos na margem anterior; genas tão largas quanto os olhos de perfil; vértice inchado acima dos ocelos; E2-E5 com tufos de pêlos curtos no meio.

Difere de C. anomalus Moure \& Lucas de Oliveira, 1962, facilmente pela extensão da mancha amarela facial e pela pontuação esparsa no vértice e no mesoscuto. Em $C$. anomalus as áreas ocelorbitais mais lisas, quase sem pontos e estes muito esparsos no mesoscuto e escutelo com os intervalos lisos e brilhantes entre 4 e $5 \mathrm{dp}$, mais afastados no disco do mesoscuto e do escutelo. É possivel que Panurginus callurus Cockerell, 1918, descrito de Carcarañá, Argentina, pertença a este gênero, de acordo com notas feitas por Moure, sobre o tipo no Natural History Museum em Washington em 1957. 


\section{Anthrenoides meridionalis (Schrottky, 1906)}

Protandrena meridionalis Schrottky, 1906: 314. - Moure, 1944: 108.11.

Panurginus saltensis var. nigroclypeata Friese, 1908: 27.

Panurginus flaviceps Friese, 1916: 171.

Panurginus saltensis var. nigroclypeata Friese, 1908:

Fêmea (único exemplar) no MNHU. Com as seguintes etiquetas: [S. Cruz, Brasil, coll. Speyer, sem data]; [Type] (vermelha); [Panurginus saltensis v. nigroclypeata Fr. 1907 Friese det.]; [Zool. Mus. Berlin]. Abelha quebrada. Abdômen e cabeça inteiros; o tórax quebrado e colado; com três células submarginais; clípeo e áreas paroculares.

Panurginus flaviceps Friese, 1916:

Um macho (único exemplar) no MNHU. Etiquetas: [Paraguay, Villa Rica, sem data e coletor]; [Type] (vermelha); [Panurginus flaviceps Fr., 1915 Friese det.]; [Zool. Mus. Berlin].

MOURE (1944: 108) Moure considerou esta espécie como sinônimo senior de Anthrenoides alfkeni Ducke, 1907. Realmente a presente espécie deve ser encaixada nesse gênero, que substitui Protandrena Cockerell, 1896 (Espécie tipo: Andrena maurula Cockerell, 1896, conforme designação de Sandhouse, 1943). Protandrena é um gênero neárctico com uma vintena de espécies. As espécies descritas por Ducke são de Minas Gerais e do Nordeste do Brasil. Ducke voltou atrás depois que conheceu a espécie de Schrottky e incluiu, em 1912, Anthrenoides em Protandrena.

Espécie muito comum em flores de uma espécie de Oxalis (Oxalidaceae) com corola roxa que cobria as margens da estrada de ferro Curitiba-Paranaguá no alto da Serra do Mar. Os machos constumavam ficar enrolados dentro das flores.

\section{Bicolletes nigriceps (Friese, 1916) comb.n.}

Panurginus nigriceps Friese 1916: 172.

Um macho no MNHU. Villa Rica, Paraguai. A base das tíbias anteriores e médias com mancha amarela.

\section{Chave para identificação das fêmeas}

1. Lóbulos pronotais com mancha amarela; fêmur mediano com dente ventral no

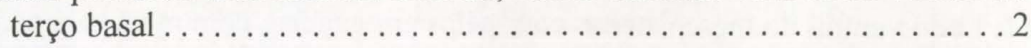

-. Lóbulos pronotais pretos; fêmur mediano no bordo inferior sem dente ventral, podendo formar ângulo marcado no terço basal . .............. 5

2. Clípeo com mancha amarela; lado ventral do mesepisterno com pêlos retos .... ......................................... pereziae

-. Clípeo preto; pêlos em gancho no lado ventral do mesepisterno .......... 3

3. Área ocelorbital com pontuação uniformemente fina e densa (cerca de 1dp); dois terços das mandíbulas amarelas .................... formosus

-. Área ocelorbital com pontuação esparsa (2-3dp) ou com área lisa sem pontos; mandíbulas castanho-escuras até pretas ................... 4 
4. Placa labral subretangular, mais larga que longa; propódeo denso-pontuado até a área basal; olhos subparalelos

paraguayanus

-. Placa labral tão larga quanto longa; propódeo sem pontos perto da área basal; olhos convergentes embaixo .................... minutus

5. Área basal do propódeo cercada atrás por faixa lisa brilhante sem pontos até a fóvea propodeal, maior que o comprimento da área basal; tergos lisos e brilhantes entre os pontos, inclusive nas depressões marginais, pontuação muito esparsa em T1-4 ........................ solani

-. Faixa atrás da área basal do propódeo reticulada e/ou pontuada; pelo menos alguns tergos reticulados entre os pontos, depressões marginais micro-reticuladas ou micro-pontuadas. . . . . . . . . . . . . . . . . . . . . . 6

6. Clípeo com mancha amarela oval no disco ................ saltensis

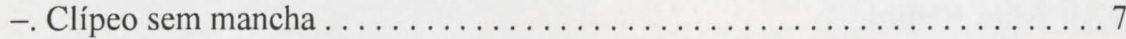

7. Clípeo opaco reticulado entre os pontos; extremidade basal das tíbias anteriores sem mancha amarela . . . . . . . . . . . . . . . . . . . . . 8

-. Clípeo liso e brilhante entre os pontos; extremidade basal das tíbias anteriores com mancha amarela . . . . . . . . . . . . . . . . . . . . . 10

8. Mesoscuto liso e brilhante entre os pontos; metasoma com brilho cúpreo ...... aeneiventris

-. Mesoscuto fortemente retículado

9. Mesoscuto com pilosidade muito curta, cerca da metade do $\varnothing$ máximo do escapo, e com pontuação densa (cerca de 1dp); carena frontal elevada, forte; nove a dez hâmulos malvacearum

-. Mesoscuto com pilosidade relativamente longa, mais que o $\varnothing$ máximo do escapo; mesoscuto com pontuação esparsa ( $>2 \mathrm{dp})$; carena frontal fraca; oito a nove hâmulos reticulatus

10. Mesoscuto com pilosidade longa quase como o $\varnothing$ máximo do escapo (em harterae e pauloensis cerca do $\varnothing$ máximo do escapo) ............ 11

-. Mesoscuto com pilosidade curta menos de três quartos do $\varnothing$ máximo do escapo

11. Lado ventral do mesepisterno com pêlos em gancho; com mancha amarela na base da tíbia média ........................ pauloensis

-. Lado ventral do mesepisterno sem pêlos em gancho; sem mancha amarela na base da tíbia média (plumosulus às vezes com uma mancha inconspícua) . . . . 12

12. Basitarsos amarelos, o médio estreito, quase quatro vezes mais longo que largo; 10 a 12 hâmulos; bordo inferior do fêmur médio em curva contínua ...... ...flavitarsis

-. Basitarsos castanhos ou pretos, o médio alargado, menos que três vezes mais longo que largo; bordo inferior do fêmur médio formando ângulo pronunciado ..................................... 13 
13. Antenas inteiramente pretas; pêlos no mesoscuto cerca do $\varnothing$ máximo do escapo; um sulco evidente acima do ocelo médio; nove a onze hâmulos ... harterae

-. Flagelo amarelo por baixo; pêlos no mesoscuto mais de duas vezes o $\varnothing$ máximo do escapo; o sulco acima do ocelo médio curto, inconspícuo; sete a nove hâmulos................................. plumosulus

14. Pontuação densa e profunda em todo o corpo, muito uniforme na cabeça e mesosoma (menos de 1dp); densa também no disco do T1; T2 com as fóveas laterais bem marcadas, profundas ................... holostictus

-. Pontuação não uniformemente densa, profunda na cabeça e mesosoma; T2 com fóveas laterais pouco evidentes, rasas . . . . . . . . . . . . . . 15

15. T1 mate reticulado entre os pontos; mandíbulas de cor acastanhada ... eustictus

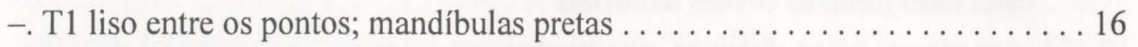

16. Lado ventral do mesepisterno sem pêlos em gancho ........... vagabundus -. Lado ventral do mesepisterno com pêlos em gancho . . . . . . . . . . . . 17

17. Mesoscuto com os intervalos brilhantes, a pontuação muito fina $(<0,02 \mathrm{~mm})$; oito a nove hâmulos ......................... guariticola

-. Mesoscuto com os intervalos reticulados; seis a sete hâmulos .......... 18

18. T1 pontuado, os intervalos lisos cerca de 1-2dp; T2 semelhante a $\mathrm{T} 1 \ldots \ldots \ldots$

hamatus

-. T1 quase sem pontos, liso; T2 com intervalos finamente reticulados, a pontuação

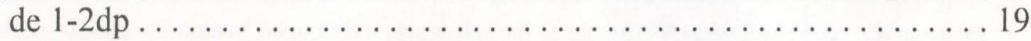

19. Mesoscuto com pontuação densa, cerca de $1 \mathrm{dp} \ldots \ldots \ldots \ldots \ldots \ldots$............ polis -. Mesoscuto com pontuação esparsa cerca de $2 \mathrm{dp} \ldots \ldots \ldots \ldots$. . brunneicornis

\section{Chave para identificação dos machos}

1. Cabeça sem desenhos amarelos . .......................... 2

-. Cabeça com desenhos amarelos $\ldots \ldots \ldots \ldots \ldots \ldots \ldots \ldots \ldots \ldots \ldots \ldots$

2. Placa labral profundamente emarginada, formando dois dentes triangulares .... flavitarsis

-. Placa labral inteira, não emarginada ...................... 3

3. Cabeça com os intervalos entre os pontos fortemente mate-reticulados ........ reticulatus

-. Cabeça com os intervalos lisos e brilhantes ................... solani

4. Labro e área supraclipeal amarelos .................... formosus

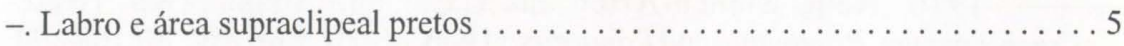

5. Placa labral triangular .................................

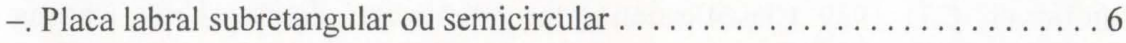

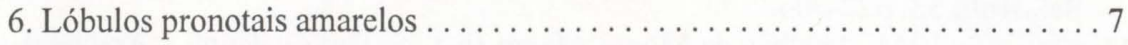

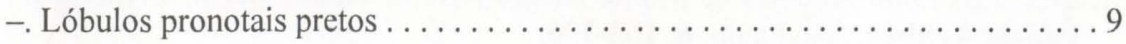


7. Face inchada; áreas elevadas acima das fóveas laterais com retículo forte, diferente dos intervalos lisos e brilhantes na cabeça; fóveas faciais direcionadas para o lado ........................... steinbachi

-. Face não inchada; sem áreas elevadas distintas acima das fóveas faciais; fóveas faciais direcionadas para a frente $\ldots \ldots \ldots \ldots \ldots \ldots \ldots \ldots \ldots$

8. Antenas inteiramente pretas $\ldots \ldots \ldots \ldots \ldots \ldots \ldots \ldots \ldots \ldots \ldots \ldots \ldots$ harterae

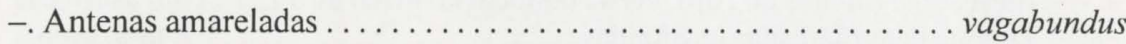

9. T4-5 com cerdas compridas eretas em franja anterior à depressão marginal; clípeo todo branco . .............................eneiventris

-. T4-5 sem cerdas em faixas; clípeo amarelo, com uma pequena mancha preta a cada lado junto as fóveas tentoriais . . . . . . . . . . . . . . . 10

10. E4 com alguns pêlos distintos, quadri-ramosos no meio, direcionados para trás saltensis

-. E4 sem pêlos quadriramosos ....................... 11

11. Clípeo e áreas paroculares amarelos ................... pereziae

-. Clípeo amarelo no centro e preto nos lados; áreas paroculares pretas ... hamatus

AGRADECIMENTOS. Agradecemos ao diretor do Museum für Naturkunde, Humboldt Universität, Berlin, Prof. Ullrich Zeller, ao diretor da seção de Hymenotpera Dr. Franz Koch pelo empréstimo dos tipos e a assistente técnica Anette Kleine-Möllhoff pela separação do material para estudo. Ao Prof. Dieter Wittmann as facilidades de trabalho no Institut für Landwirtschaftliche Zoologie und Bienenkunde da Universidade de Bonn. Ao Prof. Celso Feitosa Martins da Univ. Federal da Paraíba, João Pessoa, pela revisão do manuscrito. Ao $\mathrm{CNPq}$ pelo apoio financeiro.

\section{REFERÊNCIAS BIBLIOGRÁFICAS}

DuCKE, A. 1907. Beitrag zur Kenntnis der Solitärbienen Brasiliens, Zeitsch. f. Syst, Hymenopt. u. Dipt., 7: 305-316; 321-325; 361-368

-1908. Contribution à la connaissance de la faune Hyménoptérologique du nord-est du Brésil. Revue d'Entomol. 27: 57-87

1912. Die natürlichen Bienengenera Südamerikas. Zool. Jahrb. Abt. Syst. 34: $51-116$

FRIESE, H. 1908. Die Apidae (Blumenwespen) von Argentina, nach der Reisenergbnissen der Herren A. C. Jensen-Haarup und P. Jörgensen in der Jahren 1904-1907. Flora og Fauna, Silkeborg, 10: 1-94.

- 1916. Neue Bienen-Arten aus Chile und Südamerika. (Gatt. Camptopoeum, Psaenythia und Panurginus Hym.). Stett. Ent. Ztg. 77: 163-174 [1917].

MiCHENER, C.D. 1989. Classification of the American Colletinae. Univ. Kansas Sci. Bull. 53: 622-703.

Moure, J.S. 1944. Abelhas de Monte Alegre (Est. S. Paulo) (Hym. - Apoidea), Papéis Avulsos, São Paulo, 6: 103-126. 
SANDHOUSE, G.A. 1943. The type species of the genera and subgenera of bees. Proc. U.S. Nat. Mus. 92: 519-619.

Schlindwein, C. \& J.S. Moure. 1998. Panurgillus, gênero novo de Panurginae, com a descrição de 14 espécies do Sul do Brasil (Hymenoptera: Andrenidae). Revta bras. Zool. 15 (2): 397-439.

SCHROTTKY, C. 1906. Neue und wenig bekannte südamerikanische Bienen. Zeitsch. f. Syst, Hymenopt. u. Dipt., 6: 305-316.

STRAND, E. 1910. Hymenopterenfauna von Paraguay. Zool. Jahrb., Abt. Syst. 29: 455-562. 